\title{
MENTAL HEALTH APPLICATION PROTOTYPE WITH MACHINE LEARNING AND AUGMENTED REALITY APPLICATION DURING THE COVID-19 PANDEMIC
}

\author{
Royan Dwi Saputra ${ }^{1^{*}}$, Mella Aulia Agusty ${ }^{2}$, Jihan Hanifah ${ }^{3}$, Muhammad Rezkyandar ${ }^{4}$, Septa Inda ${ }^{5}$, \\ Abdiansah $^{6}$ \\ 1,2Information Systems, ${ }^{3,4}$ Psychology, ${ }^{5}$ Computer Systems, ${ }^{6}$ Informatics Engineering \\ Universitas Sriwijaya \\ royan.dwisaputra@gmail.com ${ }^{1 *}$ ), agustymella@gmail.com ${ }^{2}$, jihanhanifah47@gmail.com ${ }^{3}$ \\ yandarezz@gmail.com ${ }^{4}$, septainda04@gmail.com ${ }^{5}$, abdiansah@unsri.ac.id ${ }^{6}$
}

$\left({ }^{*}\right)$ Corresponding Author

\begin{abstract}
The Covid-19 pandemic has impacted all aspects of human life, regardless of the impact on mental health. Mental health is an essential issue because many people experience mental health problems, but they are appropriately not resolved. There are many methods in solving mental health problems, but not all of them can reach people due to distance, time, and costs. This study aims to explain the findings regarding an application made to minimize problems, maintain, and improve the mental health of an application called Soodo. The method used in this research is descriptive quantitative. From the findings of this study, this application can help to maintain and improve people's mental health. The results from system user testing (SUS) showed a satisfactory assessment of the Soodo application. From the results of calculations using the (SUS) method, the statistical results of the evaluation of the Soodo application prototype are Excellent or at grade A.
\end{abstract}

Keywords: Mental Health, Artificial Intelligent, Covid-19 Pandemic

\begin{abstract}
Abstrak
Pandemi Covid-19 telah berdampak pada seluruh aspek kehidupan manusia, tidak terkecuali masalah kesehatan mental. Kesehatan mental menjadi isu yang penting untuk diperhatikan karena nyatanya banyak orang yang mengalami masalah pada kesehatan mental, namun tidak diselesaikan dengan semestinya. Banyak metode dalam menanggapi dan menyelesaikan masalah kesehatan mental ini, namun nyatanya tidak semua metode tersebut dapat menjangkau orang-orang yang membutuhkan bantuan tersebut dikarenakan masalah jarak, waktu, bahkan biaya. Penelitian ini bertujuan untuk menjelaskan temuan mengenai prototipe aplikasi yang dibuat untuk meminimalisir masalah, menjaga, dan meningkatkan kesehatan mental masyarakat yang bernama Soodo. Metode yang digunakan dalam penelitian ini adalah kuantitatif deskriptif. Dari temuan pada penelitian ini, ditemukan bahwa aplikasi ini memiliki potensi untuk membantu masyarakat dalam meminimalisir, menjaga, dan meningkatkan kesehatan mental masyarakat. Dari hasil perhitungan menggunakan metode System User Testing (SUS) didapatkan hasil secara statistik penilaian terhadap prototipe aplikasi Soodo adalah Excellent atau berada pada tingkat A.
\end{abstract}

Kata kunci: Kesehatan mental, Artificial Intelligence, Pandemi Covid-19

\section{INTRODUCTION}

The Covid-19 pandemic has impacted the world community from various aspects of life. Mental health is one of the aspects affected by this pandemic due to changes in our daily lives. Situations like this force us to do physical distancing, study from home and work from home to break the virus's chain. Research conducted by (Liang, Ren, Cao, Hui, Qin, Li, \& Mei, 2020) explained that as many as $40.4 \%$ of the adolescent group tended to have mental health problems during the pandemic. Another study conducted by (Vindegaard \& Benros, 2020) explained that $96.2 \%$ of the respondents in his research had issues with mental health due to Post-Traumatic Stress Syndrome (PTSS). A subsequent study conducted by (Cullen, Gulati, \& Kelly, 2020) found that 1,210 respondents who were affected in zones that were highly 
susceptible to COVID-19 experienced mental health problems.

One thing that plays an essential role in maintaining mental health is social support. In research conducted by Mariani, Renzi, Trani, Trabucchi, Danskin, \& Tambelli (2020), it is said that amid this pandemic, social support is significant in maintaining and minimizing the negative impact of the pandemic on mental health. Another study conducted by Zysberg \& Zisberg, (2020) showed that social support and other variables related to support for groups or individuals exposed to the impact of the pandemic played the most crucial role in minimizing the effects of the pandemic mental health. In their research, Grey, Arora, Thomas, Saneh, Tohme, \& Abi-Habib (2020) show direct results that social support greatly influences stress, depression, and sleep quality during the Covid-19 pandemic.

Artificial intelligence or Artificial Intelligence (AI) is a science explicitly created for software and hardware that can imitate some of the functions of the human brain (Munawaroh \& Ratama, 2019). According to Hashimoto, Rosman, Rus, \& Meireles, (2018), artificial intelligence can be interpreted as the study of algorithms that make machines able to reason and perform cognitive functions such as problem-solving, object and word recognition, and decision making. Since 1956, artificial intelligence has undergone many developments in various lifelines. One of them is machine learning, which can recognize the human voice by studying it to create communication between machines and humans (Sudaradjat \& Suryanto, 2020). Devices capture voice signals from humans, then the information such as grammar, tone, and emotions are learned by machines. These are examples of voice machines knowing that we often encounter Google's virtual assistant on Android and Siri on iOS. Both of these applications carry out commands from the voice of the mobile user. In addition to artificial intelligence, the technology that has begun to be widely developed is Augmented Reality (AR). According to Itzstein, Billinghurst, Smith, \& Thomas (2020), AR is a technology that adds virtual images to real-world views to be seen and interacted with in real time. The application of AR technology is widely applied in the game world. One of them is Pokemon GO, which allows users to interact with Pokemon monster characters generated from the device's camera projection.

In a trial conducted by Jacob Nielsen dan Tom Landauer (1993) the number of users tested was taken into account based on the usability problems found. It shows that as more users add to the usability test, the researcher will find repeated user decisions and stagnant conditions (No new things found for further study). Jacob Nielsen emphasized that the trial with five users was very appropriate so that researchers could carry out design iterations more effectively, and could delve deeper into the basic structure of the site, information architecture issues, and task flows that suit user need.

Departing from mental health problems and using technology, the researchers wanted to create a prototype of a mobile-based mental health application called Soodo. Soodo allows users to communicate with the system and displays AR characters to increase the intensity of user interactions with the system, provide mental health diagnoses, and connect users with professional psychologists if users need psychological services. So that the formulation of the problem in this study is:

1. How can this application prototype help people prevent mental illness and maintain mental health during a pandemic?

2. How does this application prototype apply information and communication technology to the mental health sector?

The purpose of making this application prototype is to help the community prevent mental illness and maintain mental health and apply information and communication technology in the mental health field.

Research conducted by Firantoko, Tolle, \& Az-zahra (2019) which uses Human-Centered Design in its research method, explains why HCD is a research method. She said it increases public knowledge about the candidate they will choose because many people do not know existing candidates' backgrounds, achievements, and track records.

A study conducted by Yulita, Algifari, Rinaldi, \& Praseptiawan (2021) explained why TCSD (Task Centered System Design) in their research is to create a website that suits user needs and organizational needs so that the OAIL website can share up-to-date and convenient information. Accessible to the user community. Meanwhile, the current research uses the prototype method to provide a more concrete picture of the products made so that it is easier to get feedback and comprehensive product evaluations.

\section{RESEARCH METHODS}

\section{Types of research}

The type of research conducted is descriptive quantitative. This research raises the topic of current phenomena or problems by seeking information by collecting data related to the subject 
in the form of numbers and interpreting the data according to the objectives to be achieved (Jayusman \& Shavab, 2020).

\section{Target/Research Subject}

The research subject is a trait, value, or attribute with certain variables owned by a person, object, or activity that can be studied and concluded (Tanujaya, 2017). The subjects of this research are Indonesian people who want to prevent mental illness and maintain mental health. For sampling, researchers conducted a survey using a google form containing several questions related to mental health conditions. They analyzed them to select them and determine several eligible subjects to be further interviewed about their problems and needs related to mental health during the pandemic.

\section{Data, Instruments, and Data Collection Techniques}

Appropriate data collection techniques and instruments can help achieve results (problemsolving) in the research process. The tool used in this study is a questionnaire or questionnaire that produces data in the form of information from respondents from several questions posed in a questionnaire or questionnaire. The techniques used to collect data in this study are as follows:

1. Questionnaire. In this study, the researcher used a closed questionnaire directly because it consisted of several questions, and the system was multiple choice. Questionnaires are also used to assess the application prototype by respondents.

2. Interviews were conducted with people who want to prevent mental illness and maintain their mental health and meet the criteria.

\section{Application Prototype Development Method.}

Figure 1 shows the stages of prototype development. The following is an explanation of the stages as follows:

1. The data collection stage is carried out using literature studies and surveys to various groups and conducting interviews with selected respondents who meet the criteria.

2. The system design stage is to compile the results of the needs analysis done previously, starting from the software format the user needs to create the system.

3. The stage of building a prototype is done by making a temporary design that focuses on presenting it to users, such as making input and output formats with the help of the Figma Application.
Prototype evaluation stage, at this evaluation stage using the SUS (System Usability Scale) method, aims to test the usability level of the prototype so that the prototype building is following the wishes of the user. This evaluation was carried out by sending the results of the prototype that has been built with the help of the maze application, which is a usability testing tool, to users. Testing was carried out supervised by the development team using video conferencing.

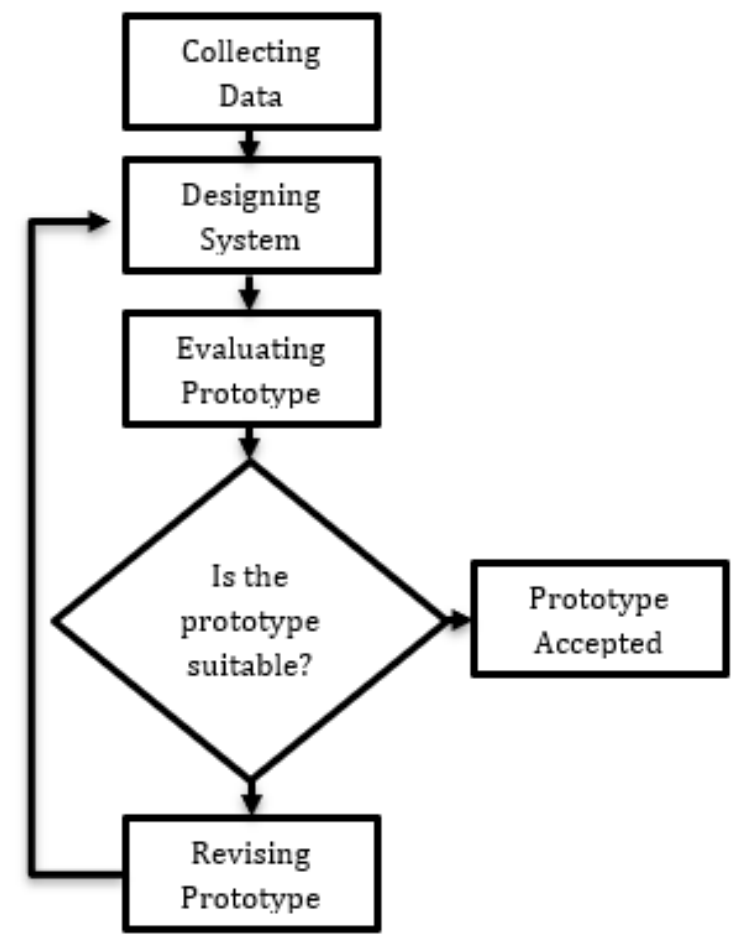

Figure 1. Application Prototype Development Method

The Review and Update Phase is carried out if, from the previous evaluation results, the user still feels that something is lacking in the built prototype. Developers need to update prototypes to suit user requirements.

\section{Application of Augmented Reality and Machine Learning on Application Prototypes}

1. Use of Machine Learning in Application Prototypes. The machine learning that was going to use in this application prototype is a chatbot. The use of a chatbot itself is designed to simulate an interactive conversation or communication between the user and the system(Oktavia, 2020).

2. The use of Augmented Reality in the application prototype. Augmented Reality in the video call feature provides accurate visualization to users 
through human characters (Rachmanto \& Noval, 2018).

\section{Application Prototype Testing Method Using System Usability Scale (SUS)}

After the device prototype, the perception of its usefulness was measured using the System Usability Scale (SUS) method in the form of a questionnaire (Sanjaya, Saputra, \& Kurniawan, 2021). When we measure with System Usability Scale (SUS) method, each question will be given a choice of a scale of 1 to 5 . Strongly disagree is worth "1," and strongly agree is worth " 5 ".

Table 1. SUS Method Criteria

\begin{tabular}{lll}
\hline SUS Score & Grade & Adjective Rating \\
\hline $\mathbf{8} \mathbf{8 0 . 3}$ & A & Excellent \\
$\mathbf{6 8}-\mathbf{8 0 . 3}$ & B & Good \\
$\mathbf{6 8}$ & C & Okay \\
$\mathbf{5 1 - 6 8}$ & D & Poor \\
$<\mathbf{5 1}$ & F & Awful \\
\hline
\end{tabular}

The formula for calculating the score of the SUS method is, look at equation 1 , as follows:

$X=\frac{\sum x}{N}$

$X=$ Average Score

$\sum x=$ Total SUS Score

$\mathrm{N}=$ Number of Respondents

\section{RESULT AND DISCUSSION}

The Result of the Design and How the Application Prototype Works

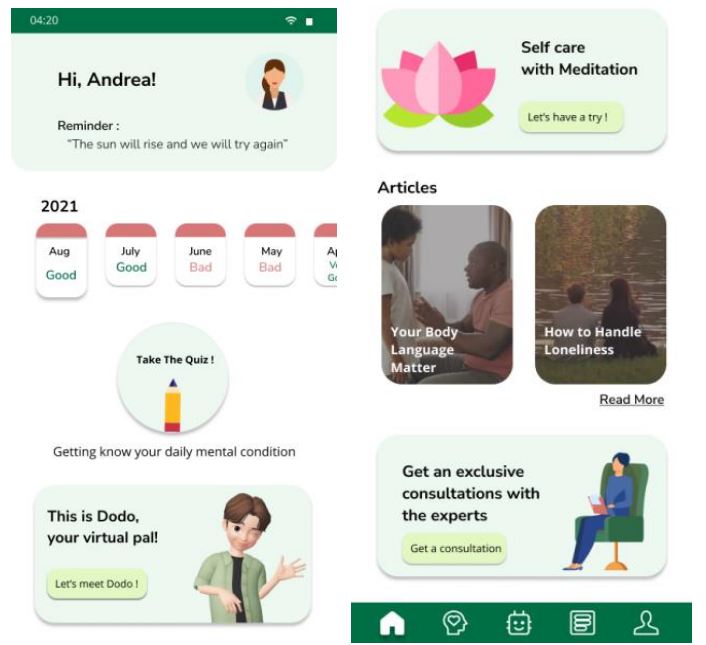

Figure 2. Homepage
Figure 2 shows the Homepage view. On this page, the main features in the Soodo application are shown so that users can immediately find out what features can be used in this application.

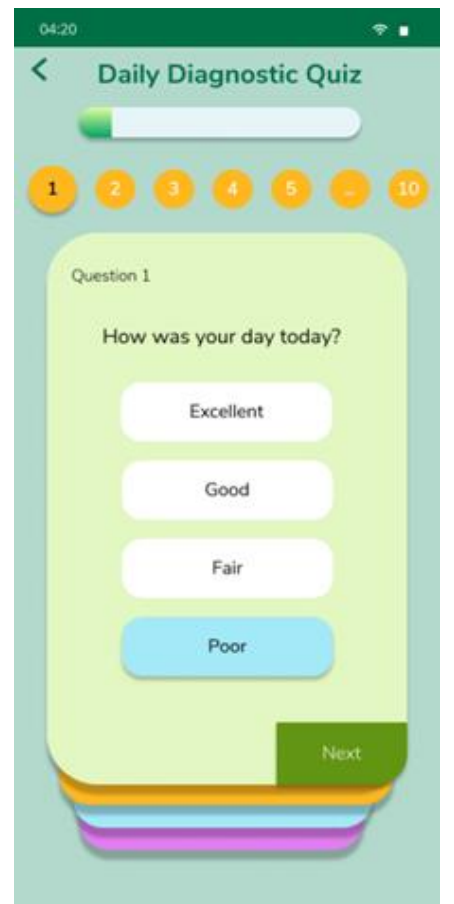

Figure 3. Daily Diagnostic Quiz

Figure 3 shows the display of the Daily Diagnostic Quiz. The user can take this quiz every day to validate the user's mental state for that day.

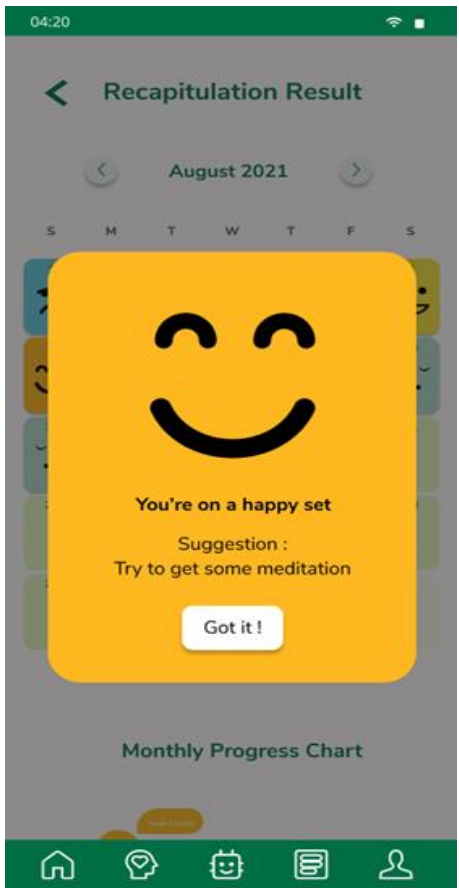

Figure 4. Daily Diagnostic Quiz Result 
Figure 4 displays the results of the Daily Diagnostic Quiz. The Soodo application will display the results of the Daily Diagnostic Quiz that the user has done. In addition to displaying a summary of the overall test results, the Soodo application also displays suggestions to balance the user's mental health state depending on the test results on that day.

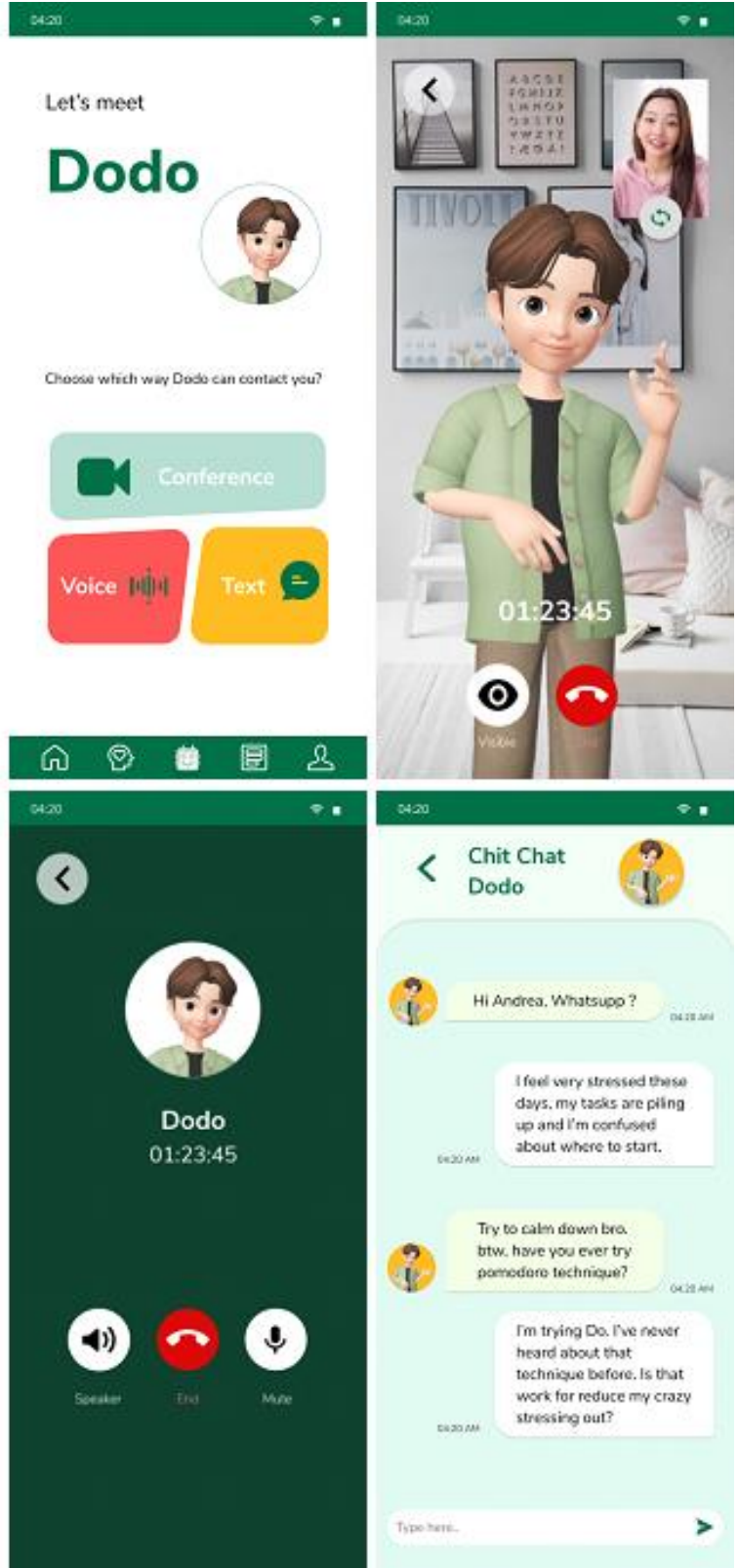

Figure 5. Virtual Friends View

Figure 5 shows the Virtual Friends menu display. The Soodo application offers a variety of ways to communicate. Users can communicate with a virtual friend named Dodo. It is a virtual character designed with Augmented Reality (AR) and Machine Learning (ML) technology so that users can see the 3-dimensional shape of Dodo and talk to Dodo. The communication media can use video calls, voice calls, and chats.

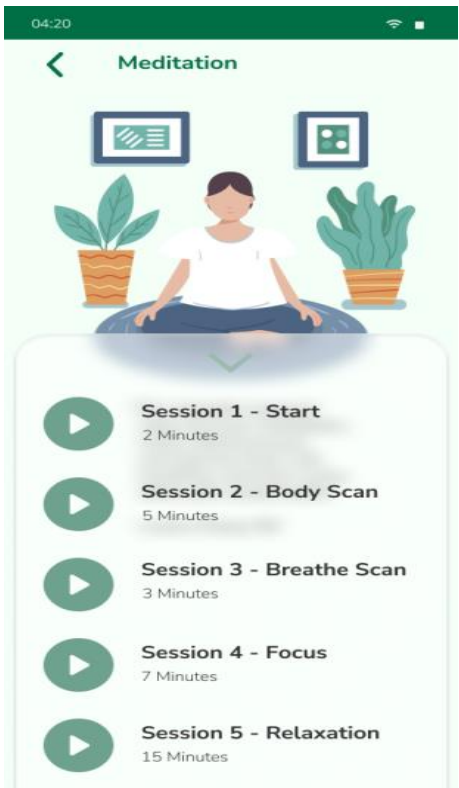

Figure 6. Meditation View

Figure 6 shows the Meditation view. This feature is support for users to maintain their mental health. The Soodo application provides a meditation feature with several sessions that users can play alternately.

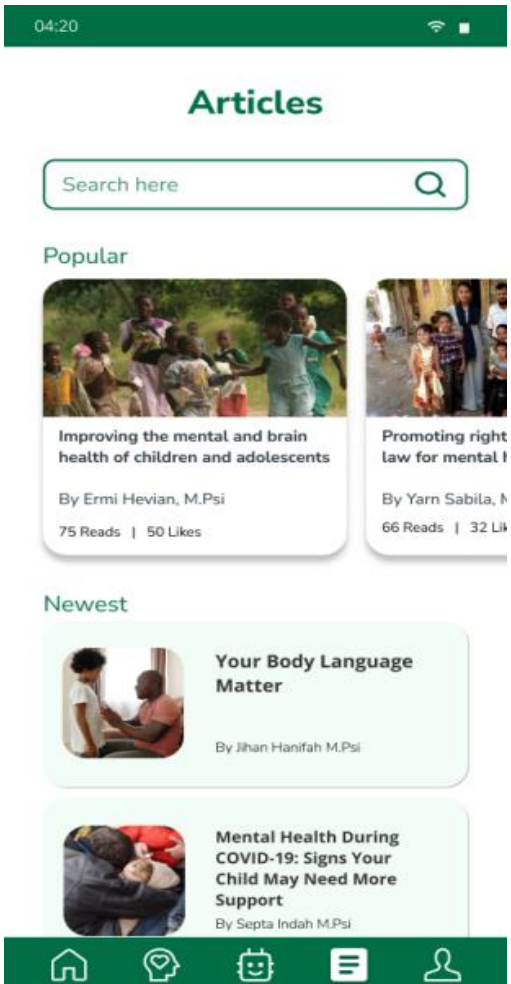

Figure 7. Articles View 
Figure 7 shows the appearance of the Articles menu. This menu is a form of the Soodo application's effort to prevent users from selfdiagnosing mental illness by providing education related to mental health written by experts.

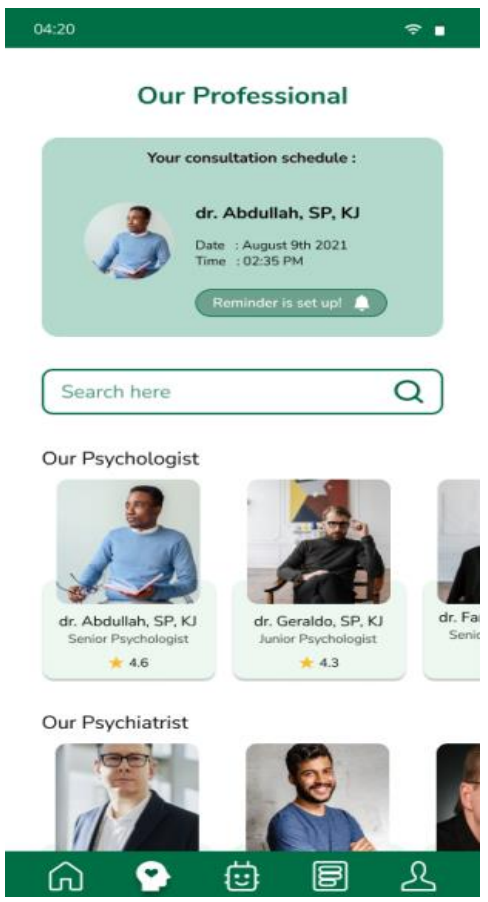

Figure 8. Professional View
Figure 8 shows the Professional menu view. The Soodo application also provides a place to consult with professional experts to make it easier for users to communicate scientifically and validly regarding their mental health.

\section{Usability Testing Results}

Researchers got 69 questionnaire respondents from all over Indonesia and took five respondents who can become users of the Soodo application prototype. The five respondents came from North Sumatra, South Sumatra, Central Java, Central Kalimantan, and South Sulawesi.

After conducting interviews, researchers tested the application prototype using the System Usability Scale (SUS) method to measure usability aspects according to the user's subjective view. From 5 respondents, the calculation of the odd number scores, the number of even scores, the total number of scores, and the SUS score obtained by each user was obtained as presented in table 2 below.

Table 2. SUS Calculation Results

\begin{tabular}{lllll}
\hline Participants & Total Odd Score & Total Even core & Total Score & SUS Score \\
\hline User 1 & 19 & 19 & 38 & 95 \\
User $\mathbf{2}$ & 17 & 18 & 35 & 87,5 \\
User 3 & 17 & 10 & 27 & 67,5 \\
User 4 & 17 & 15 & 32 & 80 \\
User 5 & 15 & 18 & 33 & 82,5 \\
\hline Average SUS Score & & & $\mathbf{8 2 , 5}$ \\
\hline
\end{tabular}

Based on table 2 above, the average SUS score obtained 82.5 with level A (Excellent). A score that reaches level A describes the Soodo application prototype that users can easily use in terms of user appearance and user experience.

\section{CONCLUSIONS AND SUGGESTIONS}

\section{Conclusion}

Based on the formulation of the problem and the results of the research that has been carried out, the researchers conclude that this application prototype can help the community prevent mental illness and maintain mental health during a pandemic based on the results of testing on five respondents. The calculation using the System Usability Testing (SUS) method shows the number 82.5, at level A or Excellent. This calculation means that the application prototype that has been built is following the needs of people who want to prevent mental illness and maintain mental health. This application prototype is also designed by applying the principles of Augmented Reality and Machine Learning to help people in the mental health sector. Augmented Reality in this application prototype is intended to provide lifelike visualizations of virtual friends to users. Meanwhile, the application of Machine Learning principles itself aims to provide feedback to users in the form of voice. This is expected to stimulate users' feelings of pleasure to maintain their mental health and prevent them from mental illness. 


\section{Suggestion}

The suggestion that researchers can give is the need for further studies or development related to the application of Augmented Reality and Machine Learning in a functional application to provide tangible benefits to the community's mental health. It is hoped that the functional application of the concepts given in this article can improve the health quality of the world community in general and the Indonesian people in particular.

\section{REFERENCE}

Cullen, W., Gulati, G., \& Kelly, B. D. (2020). Mental health in the COVID-19 pandemic. QJM : Monthly Journal of the Association of Physicians, 113(5), 311-312. https://doi.org/10.1093/qjmed/hcaa110

Firantoko, Y., Tolle, H., \& Az-zahra, H. M. (2019). Perancangan User Experience Dengan Menggunakan Metode Human Centered Design Untuk Aplikasi Info Calon Anggota Legislatif 2019. Jurnal Pengembangan Teknologi Informasi Dan Ilmu Komputer, 3(3), 2798-2806. Retrieved from http://jptiik.ub.ac.id/index.php/j-

ptiik/article/view/4795

Grey, I., Arora, T., Thomas, J., Saneh, A., Tohme, P., \& Abi-habib, R. (2020). Since January 2020 Elsevier has created a COVID-19 resource centre with free information in English and Mandarin on the novel coronavirus COVID- 19 . The COVID-19 resource centre is hosted on Elsevier Connect , the company's public news and information. Psychiatry Research, 293(January).

Hashimoto, D. A., Rosman, G., Rus, D., \& Meireles, O. R. (2018). Artificial Intelligence in Surgery: Promises and Perils. Annals of Surgery, 268(1), 70-76. https://doi.org/10.1097/SLA.0000000000002 693

Itzstein, G. S. Von, Billinghurst, M., Smith, R. T., \& Thomas, B. H. (2020). Encyclopedia of Computer Graphics and Games. Encyclopedia of Computer Graphics and Games. https://doi.org/10.1007/978-3-319-08234-9

Jayusman, I., \& Shavab, O. A. K. (2020). Aktivitas Belajar Mahasiswa Dengan Menggunakan Media Pembelajaran Learning Management System (Lms) Berbasis Edmodo Dalam Pembelajaran Sejarah. Jurnal Artefak, 7(1), 13. https://doi.org/10.25157/ja.v7i1.3180

Liang, L., Ren, H., Cao, R., Hu, Y., Qin, Z., Li, C., $\&$ Mei, S. (2020). The Effect of COVID-19 on Youth Mental Health. Psychiatric Quarterly,
91(3), 841-852. https://doi.org/10.1007/s11126020-09744-3

Mariani, R., Renzi, A., Di Trani, M., Trabucchi, G., Danskin, K., \& Tambelli, R. (2020). The Impact of Coping Strategies and Perceived Family Support on Depressive and Anxious Symptomatology During the Coronavirus Pandemic (COVID-19) Lockdown. Frontiers in Psychiatry, 11. https://doi.org/10.3389/fpsyt.2020.587724

Munawaroh, N. R. (2019). Konsep Kecerdasan Buatan dengan Pemahaman Logika Fuzzy dan Penerapan Aplikasi. Ponorogo: Uwais Inspirasi Indonesia.

Oktavia, C. A. (2020). Implementasi Chatbot Menggunakan Dialogflow dan Messenger Untuk Layanan Customer Service Pada E-Commerce. J I M P - Jurnal Informatika Merdeka Pasuruan, 4(3), 36-40. https://doi.org/10.37438/jimp.v4i3.230

Rachmanto, A. D., \& Noval, M. S. (2018). Implementasi Augmented Reality Sebagai Media Pengenalan Promosi Universitas Nurtanio Bandung Menggunakan Unity 3D. Implementasi Augmented Reality Sebagai Media Pengenalan Promosi Universitas Nurtanio Bandung Menggunakan Unity $3 D, \quad 9(1), \quad 29-37 . \quad$ Retrieved from http://jurnal.unnur.ac.id/index.php/jurnalfiki/article /view/237

Sanjaya, M. R. S., \& Saputra, A. (2021). Penerapan Metode System Usability Scale (SUS) Perangkat Lunak Daftar Hadir Di Pondok Pesantren Miftahul Jannah Berbasis Website. Jurnal Komputer Terapan, 7(1), 120-132. Retrieved from https://jurnal.pcr.ac.id/index.php/jkt/article/view/45 78

Sudaradjat, D., Suryanto, S., \& Rosano, A. (2020). Aplikasi Pengolahan Sinyal Suara pada Teknologi Kecerdasan Buatan. INSANTEK-Jurnal Inovasi ..., 1(2), 88-95. Retrieved from https://ejournal.bsi.ac.id/ejurnal/index.php/insantek /article/view/9351

Tanujaya, C. (2017). Perancangan Standart Operational Procedure Produksi Pada Perusahaan Coffeein. Jurnal Manajemen Dan Start-Up Bisnis, 2(1), 9095.

Vindegaard, N., \& Benros, M. E. (2020). COVID-19 pandemic and mental health consequences: Systematic review of the current evidence. Brain, Behavior, and Immunity, 89(May), 531-542. https://doi.org/10.1016/j.bbi.2020.05.048

Yulita, W., Algifari, M. H., Rinaldi, D., \& Praseptiawan, M. (2021). Analisis dan Rancangan User Experience Website OAIL Menggunakan Metode Task Centered System Design ( TCSD ). Jurnal Sains Komputer \& Informatika (J-SAKTI), 5(2), 879-886. Retrieved from http://ejurnal.tunasbangsa.ac.id/index.php/jsakti/art icle/view/384/0

Zysberg, L., \& Zisberg, A. (2020). Days of worry: Emotional intelligence and social support mediate 
worry in the COVID-19 pandemic. Journal of

Health

Psychology.

https://doi.org/10.1177/1359105320949935 